\title{
Disillusioned Expectations of Post-Independence Epoch in Chinua Achebe’s Selected Novels
}

\author{
Hossein Karamiamidabadi \\ Islamic Azad University (Karaj Branch), Karaj, Iran
}

\author{
Jalal Sokhanvar \\ Shahid Beheshti University, Tehran, Iran \\ Islamic Azad University (Tehran Central Branch), Tehran, Iran
}

\begin{abstract}
The phenomena that have penetrated deep into the flesh of Africa and shattered the dreams of glory in this dark land are colonialism and postcolonialism. According to these political and social upheavals caused by the arrival of the white men to the dark land, some questions flash into the conscious mind as to whether national consciousness, which was forged by the native intellectuals and even some literati, managed to achieve a cornucopia of delights pursued in the anticolonial period. The other controversial question that springs to mind is whether national bourgeoisie, who came to power by the annihilation of the colonial power, helped to establish social and political change for the betterment of society as a whole. By raising these fundamental questions, the researcher strives to shed light on the duplicitous role of national consciousness and native intellectuals in pre- and post-independent epochs based on Frantz Fanon's "Pitfalls of National Consciousness" in his seminal book The Wretched of the Earth (1963). Interestingly enough, all these cataclysmic colonial and postcolonial events can be analyzed in Chinua Achebe's novels Things Fall Apart (1959), A Man of the People (1966), and Anthills of the Savannah (1987). In other words, the unbridgeable differences between the ideologies in anticolonial and postcolonial eras, which brought disillusionment in post-independent time among the indigenous people, lie in the lines of these novels.
\end{abstract}

Keywords: colonialism, postcolonialism, neocolonialism, national consciousness, native intellectuals, national bourgeoisie

\section{Introduction}

It is an inescapable fact that the colonial era in Africa was one of the dark periods in the annals of history, which had catastrophic consequences for the colonized countries and their independence in post-revolutionary period. The conspicuous results of this domination were the glorification of the first world hegemony and the debilitation of the natives' culture and tradition. As a result of this unprecedented abomination, the literati and intellectuals of the colonized nation paved the way for uniting the masses against the colonial power. In other words, by holding nationalist assumption in their works, the writers in occupied land strove to revitalize the belittled culture and ideologies of their land. Therefore, they eventually achieved their short-term goal of having an independent land free from colonial hegemony.

Hossein Karamiamidabadi, master, English Department, Islamic Azad University (Karaj Branch).

Jalal Sokhanvar, professor, Ph.D., English Department, Shahid Beheshti University; English Department, Islamic Azad University (Tehran Central Branch). 
Despite the greatness and importance of obtaining independence in African countries, the effectiveness of this historical and social phenomenon was ephemeral in post-revolutionary epoch. That is to say, the colonial power, which had been a serious menace to the stability of the region, has gradually been replaced by the neocolonial power controlled by the national bourgeoisie and its indigenous leaders. According to this political and social upheaval, the literati of Africa such as Chinua Achebe changed their focus from the external threat to the internal one. For instance, Achebe, who played a significant role in order to unite people and revive their precolonial culture against the foreign enemy, started writing about the political and economic woes in post-independent era. Thus, this distinct shift is evident by analyzing Things Fall Apart (1959) known as an anticolonial novel and on the other side A Man of the People (1966), and Anthills of the Savannah (1987) written as post-revolutionary novels.

One of the great thinkers who explicitly warned the African intellectuals and nation against the dire consequences of the national bourgeoisie in postcolonial era was Frantz Fanon. In his great masterpiece The Wretched of the Earth (1963), he emphasized that "from nationalism we have passed to ultranationalism to chauvinism, and finally to racism” (p. 156). Interestingly enough, Fanon's predictions and foresightedness can be found and reviewed in the novels written by Achebe A Man of the People and Anthills of the Savannah. The novels vividly depict that the sense of nationalism played a transient role, which has not been significant in the life of indigenous people since the formal independence announced. In addition, the national bourgeoisie dominated and penetrated deep into every part of Africa. As a result of this domination, the interest in anticolonial writing has been overshadowed by the emergence of this newly-gained power group. In this sense, the natives started to experience neocolonialism, which was not dictated by the white people. "In the colonial territories, the bourgeois cast draws its strength after independence chiefly from agreement reached with the former colonial power” (Fanon, 1963, p. 176).

Therefore, the salient point that cannot be denied is the exchange of power between the colonial country and the local indigenous group, which deteriorated the stability and unification of the nation in the postcolonial time. In other words, things started to worsen by the arrival of the national elites, who brought kleptocracy, cronyism, nepotism, and favoritism. Indeed, political and official corruption reached its zenith, and the whole country was trapped in a vicious circle and the hopes of the social and political betterment started to fade. As a result of this, the disenchantment and skepticism with the revolutionary ideals of anticolonial nationalism were blatantly obvious.

\section{Things Fall Apart}

Having felt the necessity of reviving African culture and literature against the evil intentions of colonial beliefs, Achebe wrote Things Fall Apart in order to bring back the idea of nationalism and authenticity in African identity and culture. By writing and expanding the African traditions and customs, he succeeded in his attempt to remind people that the Blacks and their culture are not inferior to the European counterparts. In fact, he accentuated the point that the masses of the colonized lands are able to stand united and determined to annihilate the superior power, which has left deep scars in the masses' consciousness since the brutal entry of the Europeans. "Colonialism was so often a matter of terrain; seizing lands, attacking and disfranchising the existing inhabitants of those lands, and changing the function, prior purpose and meanings of the now colonized terrain” (McLeod, 2000, pp. 1-2).

It is an indisputable fact that the arrival of missionaries in Africa must be considered as the harbingers of 
doom, which brought abject misery and poverty. That is to say, the spirit of colonialism emerged out of these unwelcome intruders, who played a leading role for the dissemination of predominant colonial ideologies. The main point that cannot be overlooked is the lack of knowledge of the natives about the intentions of the white men, as a result of this ignorance, the African people could not foresee the dire consequences of this arrival. In fact, the illiteracy and lack of vigilance among the different levels of people in African society substantially contributed to the colonial ruthlessness and cruelty. Interestingly enough, Uchendu, one of the oldest men in Okonkow's motherland, affirmed his idea toward this emergence: "We have albinos among us. Do you not think that they come to our clan by mistake, that they have strayed from their way to a land where everybody is like them?” (Achebe, 1959, p. 141).

Because of their lack of knowledge, the natives did not comprehend the newcomers' ulterior motives. Therefore, it is clear that they did not have an in-depth understanding that one day the white men could harm them and take advantage of their negligence. So by the emergence of the missionaries, people experienced a new lifestyle, which is dramatically different from the past. In other words, from that point on they were not for their own anymore, but rather they were obliged to accept the guests who were not invited by them. As a result, the tranquility of the nation and its people was beginning to fade by the arrival of messengers of doom and gloom. "Their clan is now completely empty. Even the sacred fish in their mysterious lake have fled and the lake has turned the color of blood. A great evil has come upon their land as the Oracle has warned" (Achebe, 1959, p. 140).

Religion could be abused in the way of shattering the whole existence of the African nation under the guise of liberal education. Furthermore, it is an undeniable fact that the European missionaries endeavored to kill two birds with one stone. On the one hand, by spreading the new religion among the natives they succeeded in penetrating into the mind of the people and revolutionizing their customs and traditions. On the other hand, by brainwashing indigenous people into converting to the new religion, the colonial power easily captured their land and made them entirely dependent. As a result of this dependency, the whole nation suffered from economic exploitation and cultural denigration. In addition, the new invaders succeeded in controlling all the possessions and identification of the African continent. Achebe in his novel Things Fall Apart mentioned the serious repercussions on Umuofia since the arrival of the white men. Thus, the force of this pull was succinctly captured in the following passage:

The white man is very clever. He came quietly and peaceably with his religion. We were amused at his foolishness and allowed him to stay. Now he has won our brothers, and our clan can no longer act like one. He has put a knife on the things that hold us together and we have fallen apart. (Achebe, 1959, p. 176)

In this sense, not only was the colonial power able to take over the land, but also it captured the willpower of the natives. The indigenous people and the leaders joined the army of strangers and even worse helped them to uphold their government. As a result of this ignorance and negligence, things started to fall apart, and the authenticity of the natives' culture gradually faded away. Indeed, an unprecedented abomination sprouted up everywhere.

\section{The Disparagement of the Indigenous Culture and Literature by the Colonial Power}

The precolonial culture of the occupied land was suppressed by the glorification of the colonizer's centrality in the occupied land. The invader's power and hegemony were underpinned by the disparaging 
remarks about the native's past. Moreover, by giving emphasis to English language and literature, the invaders attempted to marginalize the native language and tried to underline the importance of English writing as a symbol of the splendid civilization and decent education. On the contrary, the native language and traditions were shown as the exemplification of barbarity and incivility. In this culture, unfortunately the indigenous people developed blind trust in settler's side and showed growing willingness to imitate the imported set of beliefs practiced by the upperhand. Therefore, the debilitating effect of this blind imitation was evident among the people in the colonized zone.

The European invaders of Africa tried to prioritize their language and culture in order to put in practice their ulterior motives of economic and educational domination over the nation in the occupied land. In addition, by publicizing the modern culture, which was utterly foreign to the traditional tribes of the colonized land, the European missionaries simultaneously conducted the diplomacy of converting the natives to the new religion and achieving their primary purpose which was an ultimate power and domination over the new land. Ania Loomba in Colonialism/Postcolonialism (1998) marks the effects of expansion of colonial literature and its crippling impacts on the colonized land:

Literary texts circulate in society not just because of their intrinsic merit, but because they are part of other institutions such as the market or the education system. Via these institutions, they play a crucial role in constructing a cultural authority for the colonizers, both in the metropolis and in the colonies. (p. 70)

Gradually, the grandiose scheme of betterment penetrated deep into the flesh of Africa, which created disastrous impacts on the lives of the masses, and the people could see the elevation of the invaders to the top level of power in their country. Because of this massive upheaval, the natives started to experience being aliens or even prisoners in their territory, and a sense of alienation toward the indigenous culture was salient among the masses in the society. The superior power made considerable effort to put in practice the idea of complete dependency and reliance of the colonized land on the colonizer. As time elapsed, not only the ordinary people but also the elites and educated figures of the society joined the European counterpart, and there was an abrupt shift from the central principles of a homeland to the imported ideas of the West.

There have been myriads of books written about Africa and its culture since the emergence of the white men in the black continent. Moreover, most of these writers were from the colonial countries. They consciously or even unconsciously attempted to narrate things from their own point of view without even caring about the customs and the culture of the native land. To put it another way, the picture that they tried to depict was so dark and uninviting that had no positive point to offer. One of the best examples is Heart of Darkness and Other Stories (1995) written by Joseph Conrad who showed Africa and its people as uncivilized and barbarous:

Imagine him here - the very end of the world, a sea the colour of lead, a sky the colour of smoke, a kind of ship about as rigid as a concertina — and going up this river with stores, or orders, or what you like. Sandbanks, marshes, forests, savages, - precious little to eat fit for a civilised man, nothing but Thames water to drink. No Falernian wine here, no going ashore. Here and there a military camp lost in wilderness, like a needle in a bundle of hay — cold, fog, tempests, disease, exile, and death, — death skulking in the air, in the water, in the bush. They must have been dying like flies here (pp. 33-34).

By reading these lines that indicate life in Africa, a reader is highly unlikely to find a positive opinion about the new land. As a result of this unfair description, step by step the illusion made by these countless writers started to turn out to be true. In this sense, the colonial power succeeded in spreading its own cultural 
hegemony among the natives and even among the educated people in different parts of the world. Indeed, the native and their culture were scrutinized and assessed through the curricula designed by the colonial power: "Four hundred years was indeed a very long time; and the hundreds and hundreds of books churned out in Britain, Europe and elsewhere to create the tradition of an Africa inhabited by barely recognizable humanity have taken their toll” (Achebe, 2000, p. 47).

To legitimize the brutality and violence practiced in the colonized land, intruders intentionally attempted to give rise to an erroneous assumption about the occupied land's history and tradition. On the one hand, the superior power helped to generate a highly skeptical look about the traditional value among the indigenous people and as a result of this evil intention, they managed to put in practice the idea of inferiority and inability of the natives in their society. On the other hand, by creating and writing a great number of books, they endeavored to depict Africa and its tradition in a way they had hypothesized. Therefore, they had the destructive tendency to prove that the history of the occupied land and its ancestors had nothing to offer except absolute silence.

Owing to this internal and external indoctrination, the colonial power succeeded in publicizing a new concept about the African land. In other words, they facilitated the colonial beliefs and ideologies. In addition, the colonized people became increasingly dubious about their past and religion, so they were willing to model themselves after the white men. Moreover, things represented historical and social traces of blackness were nearly obliterated. Patrick C. Nnoromele in his article "The Plight of a Hero in Achebe's Things Fall Apart" (2010) underlines that:

So when some members of the Umuofia community unwillingly accepted the invitation and endorsed "a strange faith,” things fell apart for the Igbo people in Achebe’s novel. Umuofia integrated, organic community was irreparably fractured. Their gods were blasphemed and their hero disabled. Their customs were desecrated and shattered. The people were divided or put asunder. The British district Commissioner took charge and controlled the people, so we have what seems like a total imposition of one cultural, social, and political structure upon another. (p. 40)

As a result of political and social denigration, the indigenous culture and literature began to be overshadowed by the salient ideas and beliefs related to the Western side. In other words, the colonial power dominated its own presence not only physically but also mentally.

\section{A Valiant Attempt to Restore the Stolen Identity}

To mount stiff resistance to the erroneous beliefs of the colonial writers, who were always pontificating about the lack of identity and history in colonized land in Africa, Achebe in Things Fall Apart endeavored to revive the neglected African culture and tradition by narrating the precolonial events and set of beliefs among the indigenous people to fill the large gap caused by the European encroachment. Having confronted this lack of written documents, he attempted to underline the importance of storytelling in Igbo culture in Nigeria in order to get the idea of blackness in his land in precolonial era. By narrating a story of a self-made man such as Okonkwo, who is an independent decision maker that can overcome the difficulties of life, Achebe emphasizes the falsity of European academicians and politicians about the history and tradition of the dark land.

To begin with, it is undeniable that the idea of otherness, which was blatant among the colonized people and intellectuals, had to be rooted out. Nevertheless, the eradication of this fallacious belief needed a strenuous effort, which did not occur in a short period of time. Therefore, one of the main goals of literati in Africa was to illuminate the differences between the colonized and colonizer's history and culture. By differentiating these 
sets of beliefs, they were able to forge a sense of cultural and national independence. Thus, they could write their own history which was totally different from the European dictated type:

[i]t is through this process of education that the cultural domination of the colonial power can be eradicated and a new national culture established into which the mass of the people can be integrated. It is the restructuring of consciousness that become central to the decolonization process. (Ahluwalia, 2001, p. 42)

To vigorously resist the unprecedented abomination spread by the European intruders, African writers and intellectuals got to the point that cultural revitalization must be their first priority. As a result, they started writing about different tribes and nations in Africa to depict that the idea of lack of humanity and barbarism preached by the European missionaries and academicians about the natives cannot be approved by the African culture and tradition. Initially, it seemed impossible to make their voice heard through the dominant ideology of the West, which has produced myriads of books on African inhabitants and their beliefs. In Colonialism/Postcolonialism, Ania Loomba (1998) emphasizes the erroneous beliefs of colonialists toward the colonized people:

Thus, laziness, aggression, violence, greed, sexual promiscuity, bestiality, primitivism, innocence and irrationality are attributed (often contradictorily and inconsistently) by the English, French, Dutch, Spanish and Portuguese colonialists to Turks, Africans, Native Americans, Jews, Indians, the Irish, and others. (p. 107)

Having been exposed to a great amount of cruelty and neglect from the colonial side, the indigenous people especially the literati of Africa showed no tendency of giving up the fierce battle. In this sense, a few prominent writers such as Achebe succeeded in throwing light on the origins of African culture:

Everywhere new ways to write about Africa have appeared, reinvesting the continent and its people with humanity, free at last of those stock situations and stock characters, 'never completely human,' that had dominated European writing about Africa for hundreds of years. (Achebe, 2000, p. 49)

Indeed, the African writers shouldered the responsibility for revitalizing the indigenous culture. They managed to clean-cut the false image of Africa represented by the colonial part.

\section{The Dramatic Shift From Anticolonial Beliefs in Things Fall Apart to Postcolonial Disillusionment in A Man of the People and Anthills of the Savannah}

Achieving formal independence and erasing the physical presence of the first world hegemony from the colonized lands could be considered as a remarkable accomplishment in the history of the African continent. A great deal of effort had been made by the literary and political figures, and the masses, who sacrificed their lives in order to overcome the colonial exploitation and domination. However, it must be reminded that this phenomenal success could not be considered the ultimate goal of this process. In other words, sticking to the greatness of national liberation and political independence was not sufficient in order to put the wheels of the once occupied territory in the path of creation and stability.

The ideologies and beliefs, which were propagated by the African literary and political figures, outlived their usefulness in the post-revolutionary epoch. Furthermore, characters such as Okonkwo in Things Fall Apart could no longer play a significant role in postcolonial society. In this sense, things started to fall apart but not by the foreign threat or the occupation of the land. On the contrary, the literati realized that the menace caused by the political elites and national bourgeoisie could be as destructive as the colonial power. In addition, the thing that worsened the matter was the substitution of the indigenous leaders' domination for the Whites'. 
Therefore, the national consciousness that used to be a key term in anticolonial struggle reached its level of insufficiency and futility.

Writers such as Chinua Achebe, who tried to spread the idea of indigenous culture against the foreign domination, shifted emphasis from the external enemy to the internal one. By writing novels like A Man of the People and Anthills of the Savannah, Achebe developed a series of penetrating insight to the unpleasant facts of postcolonial era in Nigeria. In this sense, he desperately strove to publicize the growing problems of the domestic politics and its severe consequences such as corruption and insincerity among the politicians in post-revolutionary time. Characters such as Chief the Honorable M. A. Nanga in A Man of the People and Sam, Ikem, and Chris in Anthills of the Savannah are the typical examples of the widespread corruption in Nigeria.

He endeavored to unveil the stark realities of political and social condition of the native land in post-revolutionary period. In this stage of a new era, the central focus shifted into the traumatic effects of the indigenous leaders and intellectuals. In fact, the colonial stereotypes have lost their domination by the emergence of neocolonialism. The political and social stability, which was predicted in Things Fall Apart by removal of the colonial power, has not turned out to be true. "You cannot balance one thing; you balance a diversity of things. And diversity is the engine of the evolution of living things, including living civilization" (Achebe, 2000, p. 97).

Despite the emphasis on balancing the variety of aspects in African land, Achebe's dream did not come true, and things started to go wrong. That is to say, the idea of erasing the European encroachment as a panacea for the country's economic, social, and political problems has not achieved its practicality. By experiencing the authoritarian government, which was dictated by the native intellectuals and the indigenous leaders, the literati such as Achebe figured out that national liberation and political independence could not be the key terms for the full independence. However, they are just plausible excuses for nationalist elites in order to achieve power and put their feet in the shoes of the previous colonial power. Therefore, all the mottos of the nationalism and trials of the masses in colonized land in precolonial era culminated in a power in the hands of a specific group called the national bourgeoisie. For instance, in the novels A Man of the People and The Anthills of the Savannah, the people who come to power such as Chief the Honourable M. A. Nanga, Sam Ikem, and Chris are the quintessential examples of this phenomenon.

\section{The Heavy Reliance of Postcolonial Government on the Foreign Assistance Rather Than the Indigenous Potential}

The conspicuous point that is evident in postcolonial era in Africa is the lack of creativity among the intellectuals and the masses. One of the primary reasons of this flaw is the reliance of the national bourgeoisie on colonial power. In other words, this newly-gained power group can be depicted as a mirror held up to European power. They tried to follow the way of the Western bourgeoisie by exaggerating their ability and advancement in science. Fanon in The Wretched of the Earth had successfully predicted the consequence of the arrival of this group to power:

The national bourgeoisie turns its back more and more on the interior and on the real facts of its undeveloped country, and tends to look toward the former mother country and the foreign capitals who count on its obliging compliance. As it does not share its profits with the people, and in no way allows them to enjoy any of the dues that are paid to it by the big foreign companies, it will discover the need for a popular leader to whom will fall the dual role of stabilizing the regime and of perpetuating the domination of the bourgeoisie. (p. 165) 
In this sense, the role of the people, who stood against the colonial power, was completely ignored and the whole thing went back to its previous colonial path. The point that is sad to see is the way that national bourgeoisie tried to show their dedication and commitment toward their own people. On the surface, they pretended that they do everything to use the indigenous potential in building the country and they are completely independent of the foreign side. However, in practice they totally did something different. Achebe in his novel A Man of the People vividly depicts this contradiction when the prime minister talks to his staff about tarring of a road:

Look T.C. we agreed that this road should be tarred. What is this dillying and dallying...? Which expert? So you want to listen to expert now? You know very well T.C. that you cannot trust these our boys. This is why I always say that I prefer to deal with Europeans ... what? Don’t worry about the press; I will make sure that they don't publish it.... (p. 42)

According to this conversation, it is clear that the least important point for the government is the involvement of the masses in building their own country and due to this unbridgeable gap caused by the authoritarian government the whole nation became indifferent about the future of their land. The anticolonial beliefs spread in precolonial time have been completely forgotten. In other words, the masses became increasingly disillusioned by the political and social mottos. As a result of this social indifference, the people in power completely ignored the needs of the nation for the sake of their own power.

\section{The Black Educated Elite's Chauvinism in Anthills of the Savannah}

Having experienced two successive phases of anticolonial struggle and independent period, which were coherently narrated in Things Fall Apart and A Man of the People, Achebe started writing and experiencing a new phase of Nigeria's political and social upheaval. The point that makes this phase different from the other ones is the characterization of the people in authority. For instance, in A Man of the People the main person in power Chief the Honourable M. A. Nanga, M. P. contrary to his long title was not an educated figure. However, in Anthills of the Savannah the three main characters Sam, Ikem, and Chris are educated people who studied in Britain. They came to power by military coup de tat and they pretended to have the idea of improving the political and social condition of the corrupted country.

In the later novels, the ignorance and negligence of the masses and the people in power were the main themes of the plots. Nevertheless, in the former novel the mentioned points were not emphasized. Thus, in the latter novels one of the primary points is a conflict between power and knowledge. Moreover, the people who have knowledge and education are thirsting for power and in this case they are completely ignorant of the matters of friendship and closeness to each other. That is to say, they are ready to do everything in order to gain power. In particular, the main person in power, Sam, known as His Excellency achieved power in a military coup. He, who is extremely reluctant to listen to the voice of his own nation and even his close friends, can be considered as a symbol of totalitarian dictatorship. For example, when people had a petition about the drought in their region, which has caused by Sam as an act of retaliation, he asked one of his men to go and tell them:

Find some nice words to say to them. Tell them we are tied up at this moment with very important matters of state. You know that you like, that I'm on the telephone with the president of United States of America or the Queen of England. Peasants are impressed by that kind of thing, you know. (Achebe, 1987, p. 16)

By narrating these lines, Achebe vividly depicts the leader's apathy and antipathy toward his own people, which created an unbridgeable gap between the masses and the people in authority. As it was tangible in the 
lines of the novel, talking to the president of the U.S. was more important than the problems of the people. Therefore, as a result of total indifference and lack of concern toward the welfare of the nation, the African land shifted from the phase of colonialism to national chauvinism. Although the national consciousness supposed to emancipate the people from the chains of the master, it put the African nation in the hands of the indigenous leaders who are wolves in sheep's clothing. John McLeod in his book Beginning Postcolonialism (2000) depicts the role of Anthills of the Savannah in highlighting the bitter facts of post-revolutionary epoch:

...Anthills of the Savannah offers an important critique of the nation after independence. On the one hand it suggests in a West African context that the fortunes of the nation have been damaged by a chauvinistic educated elite separated from the bulk of the people by education, class, power and privilege.... (p. 134)

The growing indifference among the masses about the political and social matters can be traced back to the actions and reactions of people in power. “...the most awful thing about power is not that it corrupts absolutely but that it makes people so utterly boring, so predictable and... just plain uninteresting” (Achebe, 1987, p. 52). Because of the elite's chauvinism in postcolonial era, the whole nation has tendency toward lack of creation and production which can be considered as an incurable disease. The nation, which can be diagnosed with the traces of inability and inferiority in achieving independence and self-sufficiency in the days of independence, is no more in search of betterment.

\section{National Consciousness and Its Consequences in Postcolonial Era in the Attitudes of Frantz Fanon and Chinua Achebe}

Beyond any shadow of doubt, national consciousness and its power helped the colonized nations in the fight against the colonial power. Many writers such as Achebe in Things Fall Apart tried to spread this idea in order to awaken the masses and intellectuals. That is to say, national consciousness was the most practical point to unite people against the foreign occupation in precolonial era. Despite the efficacy of this phenomenon, the question arises in post revolutionary era whether this idea sustained its practicality or not. Concerning the novels of Achebe and the other writers in Africa the answer to the question is no. For instance, in the novels $A$ Man of the People and specifically Anthills of the Savannah, there are no traces of success related to the national consciousness.

In addition, there is a tone of confusion and helplessness in most of literary works in the years after independence achievement. In other words, because of political and social changes which had counterproductive effects, most of the writers are dubious or even skeptical of the social and political condition. That is why, Achebe in his novel Anthills of the Savannah (1987) put emphasis on the skepticism and uncertainty of the characters about the results of the revolution:

Experience and intelligence warns us that man's progress in freedom will be piecemeal, slow and undramatic. Revolution may be necessary for taking a society out of an intractable stretch of quagmire but it does not confirm freedom, and may indeed hinder it. (p. 90)

According to the all-pervasive mood of apathy, the point that is conspicuous in postcolonial era is the absence of ideology, which does not stick to the values of national consciousness. In other words, lack of education among the masses is one of the main problems of this era, and this lack of knowledge stems from the ignorance of the native intellectuals toward the natives. Moreover, instead of sticking to the values of African society and using them in a proper way, they try to identify themselves with the Western counterparts. 
Interestingly enough, one of the characters in Anthills of the Savannah (1987) talks about Sam, the leader of the country, and his attitude toward the colonial customs: "He was fascinated by the customs of the English, especially their well-to-do classes and enjoyed playing at their foibles” (p. 45).

The point that is conspicuous during the days of post-independence is the lack of vigilance among the native intellectuals and because of this phenomenon, there is no improvement of thought visible in the mind of the masses. In other words, it is impossible to shift from national consciousness to political and educational consciousness. Unless this shift happens, the nation will not make any progress, and the whole nation will be in the hands of a small group that dominates the whole country. Fanon in The Wretched of the Earth (1963) explained in detail the role of intellectuals in post independence time:

The intellectuals who on the eve of independence rallied to the party, now make it clear by their attitude that they gave their support with no other end in view than to secure their slices of the cake of independence. The party is becoming a means of private advancement. (p. 171)

Interestingly enough, both Achebe and Fanon did their best in order to inform the world about the severe consequences of revolution without education in Africa. In other words, although they were in different countries, one in Algeria and the other in Nigeria, they had a lot of similar attitudes toward the unification of the nation and its results. For instance, Achebe, paid meticulous attention to narrate the situation in his country from the first days of anticolonial battle against the colonial power to the days of independence and its aftershocks in following years. On the other side, Fanon by his farsightedness and intelligence left no stone unturned in his book The Wretched of the Earth. He strove to warn people against the threats of nationalism and its productions. Therefore, both of them succeeded in fulfilling their duties in the realm of literature and politics in order to enlighten the African nations and the rest of the world.

\section{Conclusion}

Although independence in postcolonial era was supposed to bring social tranquility and political stability to the African nation, it caused a shift from anticolonial beliefs propagating unity and self-sufficiency to the postcolonial disillusionment and disenchantment. That is to say, the main problem of the newly-independent land was the penetration of the new phenomenon called neocolonialism practiced by national elites, who came to power in post-revolutionary era. Furthermore, the arrival of indigenous leaders to power has brought widespread corruption that widened the gap between the masses and the people in authority. According to this unbridgeable gap, the whole nation remained indifferent to their land and its future.

Therefore, the heavy reliance of post-independent government on the colonial side is one of the most blatantly obvious facts. In this sense, the indigenous potential is totally ignored by the authorities and the sense of creativity and independence fades away by the dominance of the black educated elites who are fully dependent on the achievements of the colonial power. All in all, it is an incontrovertible fact that national consciousness alone cannot be a long-lasting cure for the betterment of the society and its economy. To put it another way, the absence of ideology can be considered as one of the main problems of postcolonial nations in Africa. Unless the people in authority believe in the ability of the nation, they will not be able to achieve pure independence, which can bring social, political and economic stability to the country.

\section{References}

Achebe, C. (1959). Things Fall Apart. New York: Anchor Books. 
Achebe, C. (1966). A man of the people. New York: Anchor Books.

Achebe, C. (1987). Anthills of the Savannah. New York: Anchor Books.

Achebe, C. (2000). Home and exile. New York: Anchor books.

Ahluwalia, P. (2001). Politics and post-colonial theory: African inflections. London: Routledge.

Conrad, J. (1995). Heart of darkness and other stories. London: Wordsworth Classics.

Fanon, F. (1963). The wretched of the earth (C. Farrington, Trans.). New York: Grove Weidenfeld.

Loomba, A. (1998). Colonialism/Postcolonialism. New York: Routledge.

McLeod, J. (2000). Beginning postcolonialism. Manchester: Manchester UP.

Nnoromele, P. C. (2010). The plight of a hero in Achebe’s Things Fall Apart. In H. Bloom (Ed.), Chinua Achebe's Things Fall Apart (pp. 39-49). New York: Infobase Publishing. 